\title{
In situ dry matter, protein and neutral detergent fibre degradation kinetics of Cholistan Desert grasses
}

\author{
M.N. Tahir ${ }^{1}$, Z. Khan ${ }^{1,2}$, S. Ahmad ${ }^{3}$, M.Z. Ihsan ${ }^{4 \#, ~ M . H . ~ L a s h a r i ~}{ }^{3}$ \& M.A. Khan ${ }^{5}$ \\ ${ }^{1}$ University College of Veterinary and Animal Sciences, The Islamia University of Bahawalpur, Pakistan \\ ${ }^{2}$ Department of Animal Nutrition, University of Veterinary and Animal Sciences, Lahore, Pakistan \\ ${ }^{3}$ Department of Life Sciences, The Islamia University of Bahawalpur, Pakistan

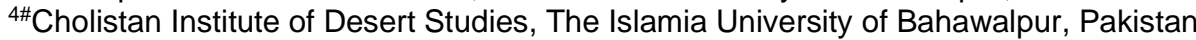 \\ ${ }^{5}$ Faculty of Veterinary Sciences, Cholistan University of Veterinary and Animal Sciences, Bahawalpur, Pakistan
}

(Received 31 January 2020; Accepted 25 March 2020; First published online ddmmyyyy)

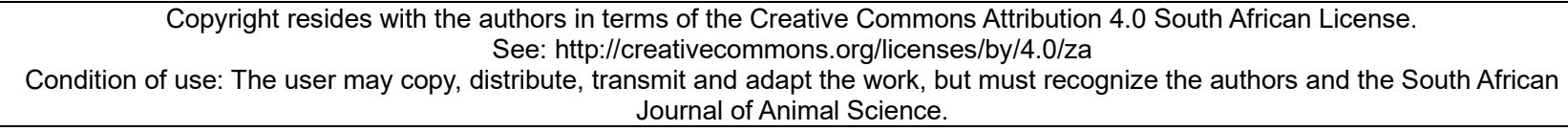

\begin{abstract}
Global climate change is evident and poses serious threats to the sustainability of traditional rangeland livestock production systems. This study tested the feeding potential of perennial grasses of Cholistan Desert for various species of ruminants at different physiological stages. Eight common and nutritionally important grass species (Cenchrus ciliaris, Stipagrostis plumose, Panicum antidotale, Cymbopogon jwarancusa, Cenchrus pennisitiformis, Lasiurus scindicus, Ochthochloa compressa and Vetiveria zizanioides) were investigated for in situ degradation parameters according to Nordic feed evaluation system (NorFor) standards. The collected, dried and milled grass samples were incubated for $0,4,8,16,24$, and 48 hours to determine dry matter and crude protein biodegradation and additionally for 96 and 168 hours for neutral detergent fibre degradation in the rumens of lactating Nili-Ravi buffalo and Cholistan Desert cows and heifers (two from each species and from each physiological stage). All of these grass species influenced the dry matter, crude protein and neutral detergent fibre degradation fractions significantly. The overall effective degradability of dry matter for asymptotic extent of degradation did not differ. However, the potentially degradable but insoluble fraction and rate of degradation were influenced significantly by the species of the animals. All the proximate parametric characteristics of perennial desert grasses were within the nutrient range for typical ruminant diets except for crude protein. It was concluded that rumen availability of grasses was highly influenced by grass species. However, these grasses are equally nutritionally important for various species of ruminants for example buffalo versus cattle at different physiological stages and heifers versus lactating animals.
\end{abstract}

Keywords: buffalo, Cenchrus ciliaris, desert cows, desert forage, feeding value

\#Corresponding author: zahid.insan@iub.edu.pk

\section{Introduction}

Cholistan desert is a part of the Great Indian Desert where it enters into Pakistan from India. It is located at the periphery of the South Punjab and comprises 2.6 million hectares of rangeland (Baig et al., 1980). It has diversified flora that can be grouped into trees, shrubs, herbs and grasses, which serve as grazing ground for 1.32 million head of livestock. The current setting of global climate change is evident and poses serious threats to the sustainability of traditional rangeland livestock production systems. This may result in serious food and water shortages for humankind over the coming decades. On the other hand, the expected demand for meat and milk consumption in global markets would increase exponentially with the expansion in human population.

In this uncertainty, the rangelands are viewed as alternative feed resources for animal production (Ashraf et al., 2013). Grazing patterns of livestock in rangelands depend on the natural ecological systems of grasses, shrubs and trees and their generative and regenerative properties, often with non-renewable inputs. On other words, the livestock graze on vegetation that grows and re-sprouts naturally without agronomic practices (Nardone et al., 2010). Wild grasses are important perennial species of Cholistan Desert, which are grazed by livestock, including cows, goats, sheep and camels (Bebawi \& Neugebhorn, 1991; Cavaye, 1991). 
These grass species are perennial xero-halophytes, which are easy to establish, have low demands for postplanting care, and occur wild in nature with extraordinary acclimatization under the severe environmental conditions of the desert (Ashraf et al., 2008). They produce a substantial amount of dry matter on saline unproductive desert soils with only intermittent rainfall. The perennial nature of these grasses can result in a sustainable and uninterrupted supply of forage throughout the year. The use of desert forage can have the additional benefits of reducing health hazards because of their antibiotic and antipyretic properties (Hameed et al., 2011). Because of these environmental and socioeconomic benefits, the nutritional content and commercial potential of these grasses should be evaluated.

The potential of these grass species has not been the subject of detailed study. Information about their adoptability, nutritional composition and digestion kinetics is therefore lacking. It is important for many reasons to look for sustainable livestock nutrition and animal forage production in particular in coming decades to fight the adverse effects of climate change. The information about the nutritional compositions of grasses that has been reported by local and international studies lacks data on digestion kinetics, and animals' responses to perennial desert grass species remain under question. Therefore, an in-situ study was planned with nylon bags and actual rumen environment. The experiment was performed to i) evaluate the agro-morphological characters of common Cholistan Desert grasses, their nutritional composition, dry matter yield and neutral detergent fibre biodegradability; and ii) to compare the data of two ruminant species for example buffalo and cattle at two physiological stages for instance heifers and lactating animals. Moreover, the current study would highlight the potential of rangeland grasses for arable farming as climate-resilient fodder to fulfil the forage requirements of the livestock.

\section{Material and Methods}

The perennial desert grasses that were used in this study were collected from various habitats of Cholistan Desert (latitude $27^{\circ} 42^{\prime}$ and $29^{\circ} 45^{\prime} \mathrm{N}$ longitude and $69^{\circ} 52^{\prime}$ and $75^{\circ} 24^{\prime} \mathrm{E}$ ) from a range of sites from July to December 2016. High temperatures and low rainfall are prominent features of this sandy desert. The desert has perennial herbaceous cover, although the plant growing seasons are from July to September and January to March.

To collect the forage samples of animal feed-related important grasses, a field survey of Cholistan Desert was conducted, keeping in mind the opinions of animal and plant experts and the points of view of the herders. The samples were collected according to the method described by Ashraf et al. (2013). The sampling was performed in triplicate from each grass habitat, and the minimum sampling distance was maintained at least $200 \mathrm{~m}$ apart. The stubbles of these grasses were planted at the field research station of Cholistan Institute of Desert Studies, Islamia University of Bahawalpur, Pakistan. All grasses were grown according to standard agronomic practices. Eight grass species were selected for nutritional and rumen degradability trials based on their establishment potential and preference by grazing animals. The grasses that passed the screening trials were Cenchrus ciliaris, Stipagrostis plumose, Panicum antidotale, Cymbopogon jwarancusa, Cenchrus pennisitiformis, Lasiurus scindicus, Ochthochloa compressa, and Vetiveria zizanioides.

The agro-ecological characteristics, growth cycle and soil habitats of these grasses are provided in Table 1. These grasses were cut after eight weeks of planting at the peak of their vegetative growth for morphological studies. The herbage was harvested $10 \mathrm{~cm}$ above the ground surface and stored for subsequent physiochemical analysis. The herbage was chopped with a nominal chop length of $20 \mathrm{~mm}$ and laid under the shade to dry. The dried samples were transported to the Livestock Production and Management Section, University College of Veterinary and Animal Sciences, Islamia University of Bahawalpur, Pakistan. For in situ incubation studies, dried samples of the grasses were ground to fine powder to pass through a $2 \mathrm{~mm}$ screen. For nutritional analysis, these dried samples were further ground to a size of $1 \mathrm{~mm}$. Plastic jars were used to store the ground dried samples for further analysis. 
Table 1 Agro-ecological characteristics of researched perennial desert grasses along with their soil habitat sampled from various locations of Cholistan Desert

\begin{tabular}{|c|c|c|c|c|c|c|}
\hline Genus and species ${ }^{1}$ & $\begin{array}{c}\text { Plant height, } \\
\mathrm{cm}\end{array}$ & $\begin{array}{l}\text { Inflorescence } \\
\text { length, cm }\end{array}$ & Growth type & Life cycle & Soil type & Presence \\
\hline Cenchrus ciliaris & $80-95$ & $5.2-10.7$ & Therophyte & Perennial & Sand dune & Abundance \\
\hline Stipagrostis plumose & $33-40$ & $6.1-12.3$ & Therophyte & Perennial & Sand dune & Abundance \\
\hline Panicum antidotale & $89-105$ & $16.3-19.6$ & Hemicryptophyte & Perennial & Sand dune & Rare \\
\hline $\begin{array}{l}\text { Cymbopogon } \\
\text { jwarancusa }\end{array}$ & $51-63$ & $18.3-32.1$ & Hemicryptophyte & Perennial & Interdunal & Abundance \\
\hline $\begin{array}{l}\text { Cenchrus } \\
\text { pennisitiformis }\end{array}$ & $62-83$ & $4.2-8.5$ & Therophyte & Annual & Sand dune & Rare \\
\hline Lasiurus scindicus & $99-117$ & $19.2-26.6$ & Phanerophyte & Perennial & Sand dune & Abundance \\
\hline $\begin{array}{l}\text { Ochthochloa } \\
\text { compressa }\end{array}$ & $23-30$ & $1.5-4.1$ & Hemicryptophyte & Perennial & Interdunal & Abundance \\
\hline Vetiveria zizanioides & $180-220$ & $22.6-28.2$ & Phanerophyte & Perennial & $\begin{array}{l}\text { Sandy } \\
\text { loam }\end{array}$ & Rare \\
\hline
\end{tabular}

${ }^{1}$ Common names: Cenchrus ciliaris: dhaman, Stipagrostis plumose: Lum, Panicum antidotale: morrot, Cymbopogon jwarancusa: khavi, Cenchrus pennisitiformis: lidder, Lasiurus scindicus: sewan, Ochthochloa compressa,: gandeel, Vetiveria zizanioides: khas

Three replicates of the chemical analyses were performed on the dried grass samples. First, the samples were oven dried $\left(60^{\circ} \mathrm{C}\right)$ for two days to obtain dry matter concentration. To determine the ash content, the dried grasses in measured amounts were put in a muffle furnace at a temperature of $500-600$ ${ }^{\circ} \mathrm{C}$ for more than five hours (AOAC, 1990; method 923.03). Crude protein (method 7.015) and ether extract (method 7.062) were also determined following procedures of the AOAC (1990). To determine the amylasetreated neutral detergent fibre concentration, the procedure described by Van Soest et al. (1991) was used with a slightly modified protocol in which heat stable alpha amylase and sodium sulphite were added to the reaction (Mertens et al., 2002).

The animals were kept at the livestock farm of Islamia University of Bahawalpur and maintained according to the criteria of the University's Animal Care and Management Committee. Eight rumencannulated animals, that is, two heifers and two lactating females representing Nili Ravi buffaloes and Cholistan Desert cattle, were used simultaneously for in situ incubation of the grass samples. Live weights of the buffaloes and cows were $519 \pm 46 \mathrm{~kg}$ and $300 \pm 32 \mathrm{~kg}$ and they produced $3.34 \pm 0.271 \mathrm{~kg} /$ day and 5.63 $\pm 0.207 \mathrm{~kg} /$ day of milk, respectively. The animals were fed individually and supplied with fresh drinking water.

The cannulated animals were fed according to NorFor standards for cannulated animals to meet their daily dietary requirements (Volden, 2011). On a dry matter basis, the roughage to concentrate ratio was 80 : 20 for lactating animals and 90: 10 for heifers. The ingredients and nutrient compositions of the diets are presented in Table 2.

For in situ biodegradation profile studies, the grass samples were incubated in the rumen of the experimental animals for different periods. NorFor standards were followed to determine the degradation profiles of the grasses (Åkerlind et al., 2011; Volden, 2011). Sub-samples (approximately $1 \mathrm{~g}$ ) were incubated for $0,4,8,16,24$, and 48 hours dry matter and crude protein biodegradation and additionally for 96 and 168 hours for neutral detergent fibre degradation. On completion of the incubation time, the bags were removed, washed with tap water and stored at $-18{ }^{\circ} \mathrm{C}$. The stored bags were once again washed with tap water in a washing machine for twelve minutes after thawing at room temperature. The dry matter loss and the amylase-treated neutral detergent fibre concentration were determined from the dried residues in the incubated bags. 
Table 2 Ingredients and mean chemical composition of the diets offered to rumen-cannulated animals $(\mathrm{g} / \mathrm{kg}$ DM unless otherwise stated $)^{1}$

\begin{tabular}{lcc}
\hline Ingredients (as fed basis) & Lactating animals & Heifers \\
\hline Sorghum & 844 & 771 \\
Lucerne hay & 88 & 195 \\
Cotton seed cake & 30 & 0 \\
Concentrate mixture & 37 & 34 \\
Forage to concentrate ratio (DM) & $80: 20$ & $90: 10$ \\
Chemical composition (DM) & & \\
Dry matter & 302 & 360 \\
Crude protein & 58 & 60 \\
Ether extract & 18 & 17 \\
Neutral detergent fibre & 583 & 567 \\
Non-fibre carbohydrates & 227 & 241 \\
Ash & 113 & 113
\end{tabular}

${ }^{1}$ Number of samples: 5; number of replicates: 2; total number of observations per feed: 10

A first order kinetic model was applied for curve fitting regression analysis (Ørskov \& McDonald, 1979). The washable fraction (a) or particle loss and non-washable fraction were two broad divisions of the in-situ degradation data. The remaining non-washable segment was sub-divided into possibly degradable $(b)$ and totally indigestible fractions.

$$
Y_{t}=a+b(1-\exp (-k d \times t))
$$

Where: $Y_{t}$ denotes the degraded fraction at a given time $t$ and $k d$ denotes the fractional degradation rate of fraction $b$. The effective dry matter degradability $(E D)$ was also calculated.

$$
E D=a+\frac{b x k d}{k d+k p}
$$

The fractional rate of passage $(k p)$ was assumed to be $0.05 / h$ for the forages. Previously, several protein evaluation systems had used this value of $k p$ (Hvelplund \& Weisbjerg, 2000).

These data were then analysed with the GLM procedure of Minitab® 16.1.1.0 (State College, Pennsylvania, USA). Each cannulated animal was treated as an experimental unit. The effects of feed, species and physiological stage of the animal were evaluated using this model.

$$
Y_{i j k l}=\mu+F_{i}+S_{j}+P_{k}+e_{i j k l}
$$

Where: $Y_{i j k l}$ denotes dependent variable measured with the th animal,

$\mu=$ overall mean,

$F_{i}=$ effect of feed $i$,

$S_{j}=$ effect of specie of $j^{\text {th }}$ animal,

$P_{k}=$ effect of physiological stage $k$ and

$e_{i j k l}=$ residual error.

\section{Results and Discussion}

The desert grass species varied significantly in height, inflorescence length, growth cycle, soil habitat and population density (Table 1). Plant height and inflorescence length had two average values; the first was an average of minimum values, and the second an average of maximum values. Vetiveria zizanioides produced the tallest plants $(220 \mathrm{~cm})$ and Cymbopogon jwarancusa had the longest spikes $(32.1 \mathrm{~cm})$. All of these grasses were perennial in nature, except for Cenchrus pennisitiformis, which is an annual. Most, but not all of these grasses were abundant in the field and were found in the sand dune habitat. 
Vetiveria zizanioides produced the maximum dry matter content $(98.3 \mathrm{~g})$ and was statistically similar to Ochthochloa compressa and Lasiurus scindicus. The grass species Stipagrostis plumosa recorded the minimum dry matter content among all of these species. The crude protein content ranged from 25 to 77.9 $\mathrm{g} / \mathrm{kg}$ on a dry matter basis and was highest for Cenchrus ciliaris and lowest for Lasiurus scindicus (Table 3). Vetiveria zizanioides produced the maximum dry matter accumulation but had an average amount of crude protein. Panicum antidotale had the second highest crude protein content $(65.1 \mathrm{~g} / \mathrm{kg}$ dry matter) after Cenchrus ciliaris. Most of these species were lower in crude protein than is recommended for functional ruminant diets $(70-200 \mathrm{~g} / \mathrm{kg}$ dry matter). The ash content ranged from $71.3 \mathrm{~g} / \mathrm{kg}$ for Stipagrostis plumosa to $141.7 \mathrm{~g} / \mathrm{kg}$ for Ochthochloa compressa. Stipagrostis plumosa had the highest crude fibre content $(400 \mathrm{~g} / \mathrm{kg}$ dry matter), while Cymbopogon jwarancusa had the most nitrogen-free extract (570 g/kg dry matter). Ether extract was less than $30 \mathrm{~g} / \mathrm{kg}$ dry matter for almost all of the species. This is typical of grass plant species in this desert. Among these grasses, Panicum antidotale has the highest calculated metabolizable energy content (136 MJ/kg dry matter). This indicates that their nutritional composition is within the desired ranges for nutrient content of diets for ruminants.

Table 3 Nutrient composition of perennial desert grasses. Values are presented in percentages of dry matter as mean and standard deviation unless otherwise stated

\begin{tabular}{llllllllll}
\hline & & \multicolumn{7}{c}{ Grass species } \\
\hline Nutrient & & CC & SP & PA & CJ & CP & LS & OC & VZ \\
\hline \multirow{3}{*}{ Dry matter } & Mean & 96.5 & 93.0 & 95.6 & 93.9 & 96.9 & 97.2 & 97.1 & 98.3 \\
& SD & 0.16 & 1.42 & 4.37 & 0.07 & 0.26 & 0.28 & 0.23 & 0.11 \\
Crude protein & Mean & 7.79 & 4.48 & 6.51 & 3.17 & 3.45 & 2.50 & 3.61 & 4.79 \\
& SD & 0.19 & 0.46 & 0.39 & 0.15 & 0.23 & 0.06 & 0.30 & 0.19 \\
Ether extract & Mean & 1.16 & 0.93 & 1.50 & 2.81 & 1.64 & 1.16 & 1.50 & 1.48 \\
& SD & 0.01 & 0.05 & 0.03 & 0.01 & 0.12 & 0.05 & 0.03 & 0.07 \\
Crude fibre & Mean & 31.7 & 40.0 & 33.5 & 20.8 & 23.7 & 31.6 & 24.6 & 27.5 \\
& SD & 2.83 & 2.33 & 1.91 & 0.42 & 2.05 & 1.06 & 1.41 & 0.92 \\
Nitrogen free extract & Mean & 45.1 & 40.5 & 37.2 & 57.0 & 54.1 & 51.5 & 53.2 & 54.5 \\
& SD & 3.20 & 4.34 & 3.12 & 0.64 & 2.64 & 1.44 & 0.56 & 0.76 \\
Ash & Mean & 9.04 & 7.13 & 8.40 & 10.6 & 14.0 & 10.4 & 14.1 & 9.08 \\
& SD & 0.01 & 0.07 & 0.31 & 0.02 & 0.01 & 0.01 & 0.81 & 0.00 \\
Metabolizable energy ${ }^{1}$ & Mean & 12.8 & 12.6 & 13.6 & 13.2 & 12.7 & 13.0 & 12.7 & 12.4 \\
(MJ/kg DM) & SD & 0.11 & 0.30 & 0.69 & 0.02 & 0.08 & 0.07 & 0.06 & 0.06
\end{tabular}

CC: Cenchrus ciliaris; SP: Stipagrostis plumose; PA: Panicum antidotale; CJ: Cymbopogon jwarancusa; CP: Cenchrus pennisitiformis; LS: Lasiurus scindicus; OC: Ochthochloa compressa; VZ: Vetiveria zizanioides

${ }^{1}$ Metabolizable energy was calculated from chemical composition according to MAFF-1 (Ministry of Agriculture, Food and Fishiries) 1986, method 1.

The in-situ dry matter, neutral detergent fibre and crude protein biodegradation parameters were studied separately. The grass species significantly influenced $(P<0.001)$ all fractions of these parameters. The washable fraction (a) of dry matter, neutral detergent fibre and crude protein biodegradation are presented in Tables 4, 5 and 6, respectively. The highest washable fraction (0.28) was measured for Cymbopogon jwarancusa for dry matter and the lowest was for Stipagrostis plumose (0) for neutral detergent fibre biodegradation. The potentially degradable fractions (b) of dry matter ranged from 0.41 to 0.60 , of neutral detergent fibre from 0.50 to 0.75 , and of crude protein from 0.17 to 0.29 . In contrast to the washable fraction, Stipagrostis plumose had the highest value for potentially degradable fraction and Vetiveria zizanioides reported the lowest. The fractional degradation rate of fraction $b(k d)$ and degradability of dry matter at 48 hours of incubation ranged from 0.02 to 0.06 and 0.33 to 0.51 , respectively, and were highest for Cenchrus ciliaris and the least for Vetiveria zizanioides. The $k d$ and degradability of neutral detergent fibre degradation at 48 hours ranged from 0.02 to 0.05 and 0.16 to 0.33 and were the highest for Cenchrus pennisitiformis and lowest for Vetiveria zizanioides. At 169 hours of incubation the neutral detergent fibre degradation ranged from 0.20 to 0.35 and was the highest for Cenchrus pennisitiformis and again lowest for 
Vetiveria zizanioides (Table 5). The $k d$ and degradability of crude protein degradation after 48 hours of incubation ranged from 0.02 to 0.11 and 0.12 to 0.20 and were highest for Panicum antidotale and lowest for Cenchrus ciliaris and Cenchrus pennisitiformis. The grasses were ranked in order of decreasing dry matter degradability: Cenchrus ciliaris = Cenchrus pennisitiformis $>$ Cymbopogon jwarancusa $>$ Panicum antidotale > Ochthochloa compressa > Lasiurus scindicus > Stipagrostis plumosa > Vetiveria zizanioides.

Table 4 Effect of feed, species or physiological stage of the animal on in situ dry matter degradation kinetics and effective degradability of perennial desert grasses

\begin{tabular}{|c|c|c|c|c|c|c|c|c|c|c|c|c|}
\hline \multirow{2}{*}{$\begin{array}{l}\text { In situ } \\
\text { parameters }\end{array}$} & \multicolumn{8}{|c|}{ Grass species } & \multirow{2}{*}{ SEM } & \multicolumn{3}{|c|}{$P$-value } \\
\hline & $\mathrm{CC}$ & $\mathrm{SP}$ & PA & CJ & $\mathrm{CP}$ & LS & $\mathrm{OC}$ & VZ & & Feed & Species & Stage \\
\hline$a$ & 0.26 & 0.15 & 0.23 & 0.28 & 0.25 & 0.21 & 0.24 & 0.20 & 0.008 & $<0.001$ & 0.981 & 0.122 \\
\hline$b$ & 0.45 & 0.60 & 0.50 & 0.45 & 0.49 & 0.46 & 0.41 & 0.42 & 0.021 & $<0.001$ & 0.031 & 0.713 \\
\hline$k d$ & 0.06 & 0.04 & 0.05 & 0.04 & 0.05 & 0.04 & 0.04 & 0.02 & 0.003 & $<0.001$ & 0.013 & 0.708 \\
\hline DMD & 0.51 & 0.39 & 0.47 & 0.48 & 0.50 & 0.40 & 0.43 & 0.33 & 0.007 & $<0.001$ & 0.342 & 0.291 \\
\hline
\end{tabular}

CC: Cenchrus ciliaris; SP: Stipagrostis plumose; PA: Panicum antidotale; CJ: Cymbopogon jwarancusa; CP: Cenchrus pennisitiformis; LS: Lasiurus scindicus; OC: Ochthochloa compressa; VZ: Vetiveria zizanioides

$a$ : washable fraction $b$ : potentially degradable fraction; $k d$ : fractional rate of disappearance of fraction $b$; DMD: effective DM degradability at 48 hours of incubation

Table 5 Effect of feed, species and physiological stage of the animal on in situ neutral detergent fibre degradation kinetics and effective degradability of wild grasses from Cholistan Desert

\begin{tabular}{|c|c|c|c|c|c|c|c|c|c|c|c|c|}
\hline \multirow{2}{*}{$\begin{array}{l}\text { In situ } \\
\text { parameters }\end{array}$} & \multicolumn{8}{|c|}{ Grass species } & \multirow{2}{*}{ SEM } & \multicolumn{3}{|c|}{$P$-value } \\
\hline & $\mathrm{CC}$ & SP & PA & CJ & $\mathrm{CP}$ & LS & OC & VZ & & Feed & Species & Stage \\
\hline$a$ & 0.03 & 0.00 & -0.01 & 0.04 & 0.05 & 0.04 & 0.08 & 0.03 & 0.006 & $<0.001$ & 0.101 & 0.997 \\
\hline$b$ & 0.64 & 0.75 & 0.71 & 0.63 & 0.66 & 0.59 & 0.53 & 0.50 & 0.008 & $<0.001$ & 0.610 & 0.853 \\
\hline$k d$ & 0.05 & 0.03 & 0.04 & 0.03 & 0.04 & 0.04 & 0.04 & 0.02 & 0.002 & $<0.001$ & 0.109 & 0.115 \\
\hline NDFD48 & 0.31 & 0.21 & 0.24 & 0.23 & 0.33 & 0.25 & 0.33 & 0.16 & 0.008 & $<0.001$ & 0.301 & 0.097 \\
\hline NDFD168 & 0.34 & 0.28 & 0.30 & 0.28 & 0.35 & 0.28 & 0.32 & 0.20 & 0.006 & $<0.001$ & 0.109 & 0.070 \\
\hline
\end{tabular}

CC: Cenchrus ciliaris; SP: Stipagrostis plumose; PA: Panicum antidotale; CJ: Cymbopogon jwarancusa; CP: Cenchrus pennisitiformis; LS: Lasiurus scindicus; OC: Ochthochloa compressa; VZ: Vetiveria zizanioides

$a$ : washable fraction $b$ : potentially degradable fraction; $k d$ : fractional rate of disappearance of fraction $b$; NDFD48 and NDFD168: effective neutral detergent fibre degradability at 48 hours and 168 hours of incubation, respectively.

The potentially biodegradable fraction and $k d$ were influenced $(P<0.05)$ by the species of the animals, while washable fraction and dry matter degradability were not affected $(P>0.05)$ (Table 4). Neither were the neutral detergent fibre degradation fractions influenced $(P>0.05)$ by the species of the cannulated animals (Table 5). The heifers and the lactating animals in the present study did not show any significant difference in the utilization of any of the dry matter fractions $(P>0.05)$. Similar results were observed for the neutral detergent fibre fractions and crude protein. However, lactating animals tended to increase their capacity for neutral detergent fibre and crude protein degradability at both time intervals $(P=0.097-0.155$ and $P=0.070$ - 0.197 respectively). Thus, it can be concluded that the degradation of the nutrients in these desert grasses was independent of the types of animal and their physiological stages. 
Table 6 Effect of feed, species and physiological stage of the animal on in situ crude protein degradation kinetics and effective degradability of wild grasses collected from Cholistan Desert

\begin{tabular}{|c|c|c|c|c|c|c|c|c|c|c|c|c|}
\hline \multirow{2}{*}{$\begin{array}{l}\text { In situ } \\
\text { parameters }\end{array}$} & \multicolumn{8}{|c|}{ Grass species } & \multirow[b]{2}{*}{ SEM } & \multicolumn{3}{|c|}{$P$-value } \\
\hline & $\mathrm{CC}$ & SP & PA & $\mathrm{CJ}$ & $\mathrm{CP}$ & LS & $\mathrm{OC}$ & VZ & & Feed & Species & Stage \\
\hline$a$ & 0.06 & 0.02 & 0.03 & 0.01 & 0.05 & 0.01 & 0.01 & 0.00 & 0.010 & 0.006 & 0.101 & 0.907 \\
\hline$b$ & 0.29 & 0.19 & 0.25 & 0.28 & 0.28 & 0.26 & 0.17 & 0.23 & 0.011 & $<0.001$ & 0.009 & 0.753 \\
\hline$k d$ & 0.02 & 0.06 & 0.11 & 0.04 & 0.02 & 0.04 & 0.08 & 0.07 & 0.007 & $<0.001$ & 0.768 & 0.155 \\
\hline $\mathrm{CPD}_{4} 8^{2}$ & 0.13 & 0.12 & 0.20 & 0.12 & 0.14 & 0.12 & 0.12 & 0.14 & 0.015 & 0.013 & 0.008 & 0.197 \\
\hline
\end{tabular}

CC: Cenchrus ciliaris; SP: Stipagrostis plumose; PA: Panicum antidotale; CJ: Cymbopogon jwarancusa; CP: Cenchrus pennisitiformis; LS: Lasiurus scindicus; OC: Ochthochloa compressa; VZ: Vetiveria zizanioides

$a$ : washable fraction $b$ : potentially degradable fraction; $k d$ : fractional rate of disappearance of fraction $b$; CPD: effective crude protein degradability at 48 hours of incubation

Cholistan Desert is a productive rangeland that has diversified flora and serves as the milk basket of Pakistan. It includes a variety of wild growing plant species that include perennial grasses with fast growth and good dry matter accumulation. These grasses are excellent halophytes and can tolerate extreme salt levels (Naz et al., 2009). Ahmad et al. (2001) reported that Lasiurus scindicus, Cenchrus ciliaris and Aristida adscensionis are the most abundant grass species there. This study confirmed that perennial grasses Lasiurus scindicus and Cenchrus ciliaris were present in abundance at sand dunes. These wild grasses have never been tested for feeding value, nutritional composition and rumen degradability characteristics.

Degradability of the dry matter, neutral detergent fibre, and crude protein by cow and buffalo over time are presented in Figures 1,2, and 3. The highest crude protein value for Cenchrus ciliaris agreed with that of Keba et al. (2013) but was lower than that of Sultan et al. (2011) and Ashraf et al. (2013). Sultan et al. (2011) estimated in situ dry matter and neutral detergent fibre digestibility kinetics during a 45-day trial on rumen cannulated buffalo bulls for various cultivated grasses. They found the highest rumen dry matter degradability values for Panicum antidotale (0.742) and the lowest for Vetiver zizanioides (0.295). The highest estimated neutral detergent fibre degradability values were observed for Panicum antidotale (0.679) and the lowest for Leptochloa fusca (0.277). The present results agree with those of Sultan et al. (2011) for dry matter degradability of grasses. During their experiment on cannulated Nili-Ravi buffalo and Cholistan Desert cattle, Tahir et al. (2017) evaluated and observed higher values of rumen dry matter degradation for legume and cereal forages than for range grasses. Habib et al. (2013) compared the rumen degradation kinetics in buffalo steers of different origins for oilseed and cereal grains. The present results depicted a significant difference in the rumen degradation kinetics and effective degradability for neutral detergent fibre and crude protein biodegradability. Trials conducted on cannulated riverine buffaloes and cows that were offered tropical forage grasses reported no difference in rumen dry matter and neutral detergent fibre degradability. However, $k d$ values were higher in buffaloes than in cows (Franzolin \& Dehority, 1999). Linden et al. (2014) conducted an experiment in which they offered chopped warm-season grass hay individually for ad libitum intake. They did not observe any differences in digestibility between cows and heifers. However, a difference was found between pregnant and non-pregnant cows. Similarly, Tahir et al. (2019) found no differences in dry matter degradability or $k d$ values of legume and cereal forages between heifers and lactating animals when these feeds were studied using the in-situ technique. Weiss and Shockey (1991) reported that an increased forage to concentrate ratio did not affect dry matter degradability when highquality orchard grass and alfalfa silages were the forage sources. It is noteworthy that the heifers and lactating animals were offered a standard diet with different forage to concentrate ratios. The dietary forage to concentrate ratio and processing of forage had a non-significant effect on the extent of digestion of grass cell wall components. 


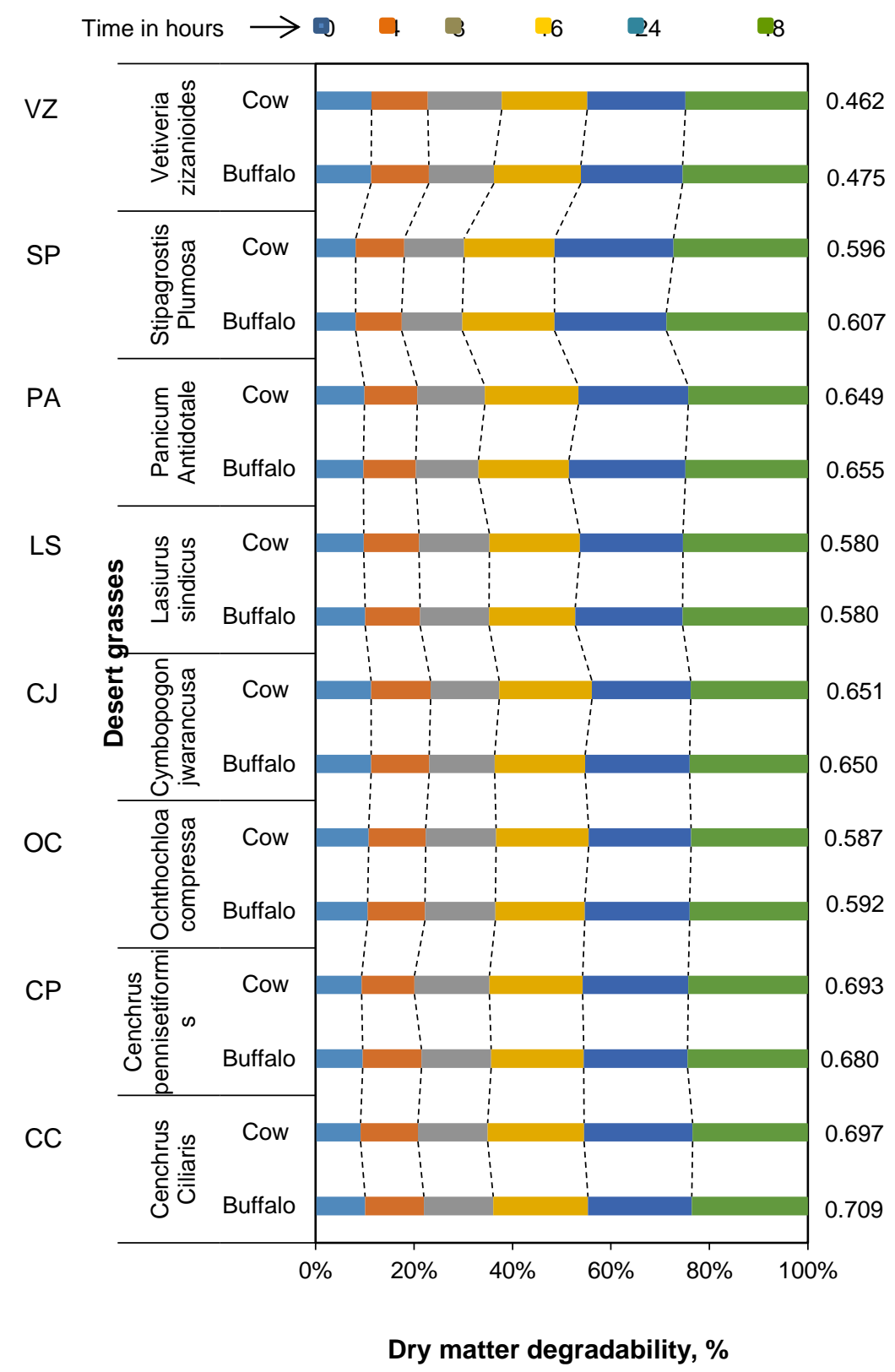

Figure 1 Degradability of dry matter by cow and buffalo over time of different perennial grasses from Cholistan desert

CC: Cenchrus ciliaris; SP: Stipagrostis plumose; PA: Panicum antidotale; CJ: Cymbopogon jwarancusa; CP: Cenchrus pennisitiformis; LS: Lasiurus scindicus; OC: Ochthochloa compressa; VZ: Vetiveria zizanioides 


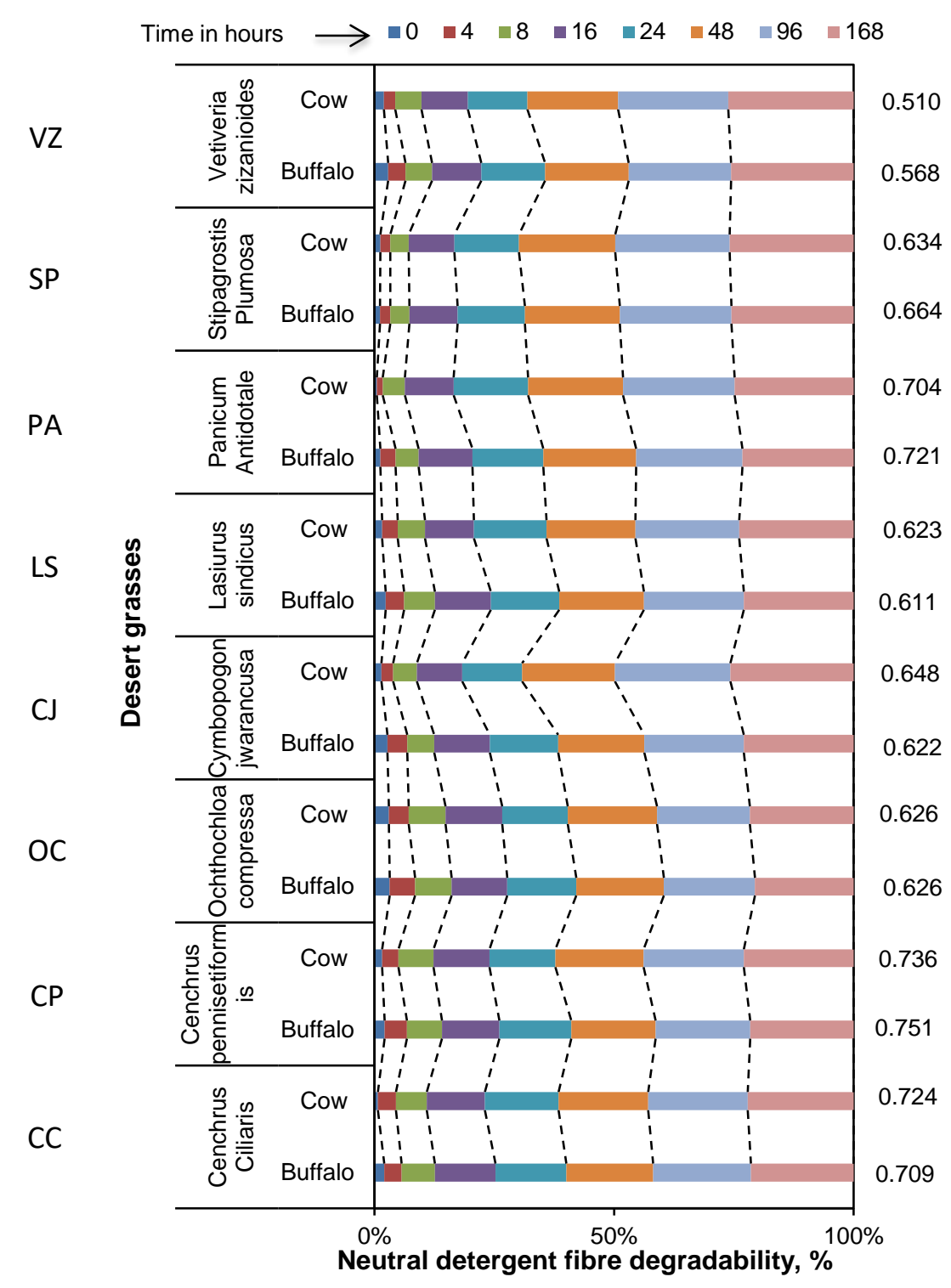

Figure 2 Degradability of neutral detergent fibre by cow and buffalo over time of different perennial grasses from Cholistan Desert

CC: Cenchrus ciliaris; SP: Stipagrostis plumose; PA: Panicum antidotale; CJ: Cymbopogon jwarancusa; CP: Cenchrus pennisitiformis; LS: Lasiurus scindicus; OC: Ochthochloa compressa; VZ: Vetiveria zizanioides 


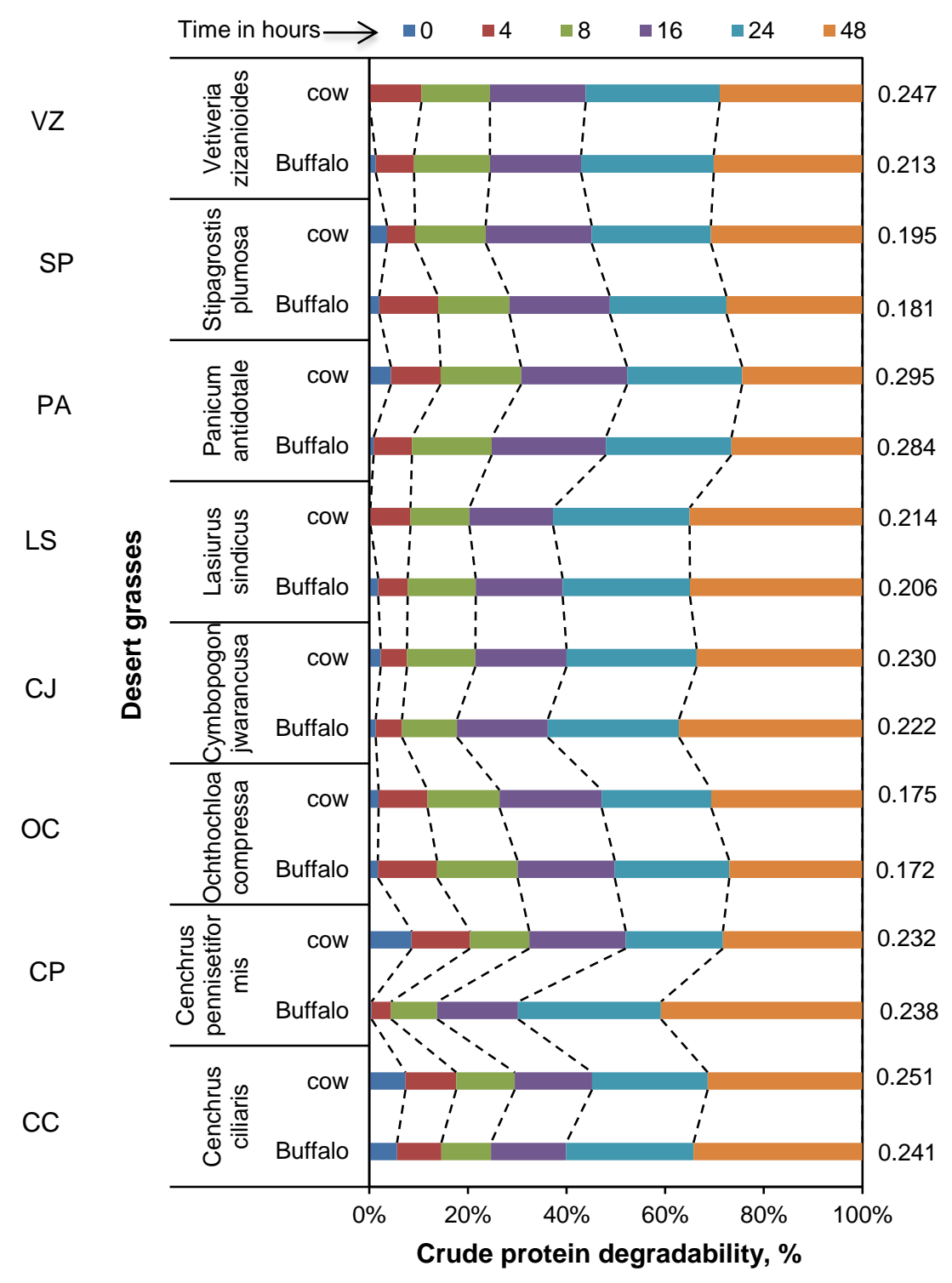

Figure 3 Degradability of crude protein by cow and buffalo over time of different perennial grasses from Cholistan Desert

CC: Cenchrus ciliaris; SP: Stipagrostis plumose; PA: Panicum antidotale; CJ: Cymbopogon jwarancusa; CP: Cenchrus pennisitiformis; LS: Lasiurus scindicus; OC: Ochthochloa compressa; VZ: Vetiveria zizanioides

\section{Conclusion}

These desert forage grasses, especially Cenchrus ciliaris and Panicum antidotale, have excellent feeding value and nutritional profile for livestock. They are adaptable and have promising forage yield and nutritional profiles. They are characterized by rapid degradability in the rumen. Thus, they are promising as sources of forage for buffalo and cattle, whether they are lactating or not. The introduction of these grasses would enable use of these desert grasses as alternate forage for sustainable livestock production in future.

\section{Acknowledgments}

The authors wish to thank Higher Education Commission (HEC) of Pakistan for their financial support (P-3168) for the research presented in this paper.

\section{Authors' contributions}

MNT conceived and designed the investigation. MNT, ZK and MZI conducted the research. MNT, SA, and MHL 
analysed the data. MNT and MAK developed new methods and models, and the original manuscript was written by MNT and $\mathrm{MZI}$.

\section{Conflict of Interest Declaration}

The authors declare that they have no conflict of interest.

\section{References}

Åkerlind, M., Weisbjerg, M.R., Eriksson, T., Tøgersen, R., Udén, P., Ólafsson, B.L., Harstad, O.M. \& Volden, H., 2011. Feed analyses and digestion methods. NorFor (Nordic Feed Evaluation System) EAAP 130. H. Volden, Wageningen, The Netherlands, pp. 41-54.

Ahmad, I., Arshad, M. \& Bibi, H., 2001. Phytogeographical distribution of vegetation in desert area of Islamia University, Bahawalpur. J. Biol. Sci. 1, 768-771.

Ashraf, M.A., Mahmood, K., Yusoff, I. \& Qureshi, A.K., 2013. Chemical constituents of Cenchrus ciliaris L. from the Cholistan Desert, Pakistan. Archeol. Biol. Sci. Belgrade, 65, 1473-1478.

Ashraf, M., Hameed, M., Arshad, M., Ashraf, Y. \& Akhtar, K., 2008. Salt tolerance of some potential forage grasses from Cholistan Desert of Pakistan. In: Ecophysiology of high salinity tolerant plants. Springer, Dordrecht. pp. 31-54.

AOAC (Association of Official Analytical Chemists), 1990. Official methods of analysis. AOAC International, Gaithersburg, MD, USA.,

Baig, M.S., Akram, M. \& Hassan, M.A., 1980. Possibilities for range development in Cholistan Desert as reflected by its physiography and soils. Pak. J. Forest. 30, 61-65.

Bebawi, F.F. \& Neugebhorn, L., 1991. A review of plants of Northern Sudan - with special reference to their uses. Deutsche Gesellschaft fur Technische Zusammenarbeit (GTZ) GmbH. Federal Republic of Germany

Cavaye, J., 1991. The buffel book - A guide to Buffel grass pasture development in Queensland. Queensland Department of Primary Industries Information Series Q190001, pp. 1-43.

Franzolin, R. \& Dehority, B.A., 1999. Comparison of protozoal populations and digestion rates between water buffalo and cattle fed an all forage diet. J. Appl. Anim. Res. 16, 33-46.

Habib, G., Ali, M., Bezabih, M. \& Khan, N.A. 2013. In situ assessment of ruminal dry matter degradation kinetics and effective rumen degradability of feedstuffs originated from agro-industrial by-products. Pak. Vet. J. 33, 466-470.

Hameed, M., Ashraf, M., Al-Quriany, F., Nawaz, T., Ahmad, M.S.A., Younis, A. \& Naz, N., 2011. Medicinal flora of the Cholistan Desert: A review. Pak. J. Bot. 43, 39-50.

Hvelplund, T. \& Weisbjerg, M.R., 2000. In situ techniques for the estimation of protein degradability and postrumen availability. In: D.I. Givens, E. Owen, R.F.E. Axford, \& H.M. Omed. Forage evaluation in ruminant nutrition Cabi, Oxon, United Kingdom. pp. 233-258.

Keba, H.T., Madakadze, I.C., Angassa, A. \& Hassen, A., 2013. Nutritive value of grasses in semi-arid rangelands of Ethiopia: Local experience based herbage preference evaluation versus laboratory analysis. Asian Australasian $\mathrm{J}$. Anim. Sci. 26, 366-377.

Linden, D.R., Titgemeyer, E.C., Olson, K.C. \& Anderson, D.E., 2014. Effects of gestation and lactation on forage intake, digestion, and passage rates of primiparous beef heifers and multiparous beef cows. J. Anim. Sci. 92, 2141-2151.

Madsen, H.O., Garred, P., Thiel, S., Kurtzhals, J.A., Lamm, L.U., Ryder, L.P. \& Svejgaard, A., 1995. Interplay between promoter and structural gene variants control basal serum level of mannan-binding protein. J. Immunol. 155, 3013-3020.

Mertens, D.R., 2002. Gravimetric determination of amylase-treated neutral detergent fiber in feeds with refluxing in beakers or crucibles: Collaborative study. J. AOAC. Int. 85, 1217-1240.

Naz, N., Mansoor, H., Muhammad, A., Rashid, A. \& Muhammad, A., 2009. Eco-morphic variation for salt tolerance in some grasses from Cholistan Desert, Pakistan. Pak. J. Bot. 41, 1707-1714.

Ørskov, E.R. \& McDonald, I., 1979. Estimation of protein degradability in the rumen from incubation measurements weighted according to rate of passage. J. Agricul. Sci. 92, 499-503.

Sultan, J.I., Manzoor, M.N., Shahzad, M.A. \& Nisa, M., 2011. Nutritional profile and in situ digestion kinetics of some irrigated grasses at pre-bloom stage. International Conference on Biology, Environment and Chemistry. (IPCBEE). IACSIT Press, Singapore. pp. 24.

Tahir, M.N., Khan, Z., Khan, N.A., Saima, Kamran, Z. \& Inal, F., 2017. In situ dry matter degradation kinetics of tropical forages. In: P. Udén, T. Eriksson, R. Spörndly, B-O. Rustas, K.M. Kasmaei \& M. Liljeholm (eds). Proceedings of the 8th Nordic Feed Science Conference, Uppsala, Sweden. pp. 130-35. https://www.slu.se/globalassets/ew/org/inst/huv/konferenser/nfsc/nfsc-2017-proceedings.pdf

Tahir, M.N., Khan, Z., Khan, N.A., Kamran, Z., Saima, Z. \& Inal, F., 2019., Dry matter degradation kinetics of selected tropical forage in Nili-Ravi buffalo and Cholistani cows at heifer and lactating stages using NorFor in situ standards. J. Zoolog. Res. 1, 10-19.

Van Soest, P.J., Robertson, J.B. \& Lewis, B.A., 1991. Methods for dietary fiber, neutral detergent fiber, and nonstarch polysaccharides in relation to animal nutrition. J. Dairy Sci. 74, 3583-3597.

Volden, H., 2011. Feed fraction characteristics. NorFor (Nordic Feed Evaluation System) EAAP 130. H. Volden, Wageningen, The Netherlands. pp. 33-40.

Weiss, W.P. \& Shockey, W.L., 1991. Value of orchardgrass and alfalfa silages fed with varying amounts of concentrates to dairy cows. J. Dairy Sci. 74, 1933-1942. 